Neus Torbisco-Casals*

\title{
Multiculturalism, Identity Claims, and Human Rights: From Politics to Courts
}

DOI 10.1515/lehr-2016-0012

Published online November 19, 2016

Abstract: Across Europe, courts (both domestic and international) are increasingly playing a central role in dealing with identity-driven conflicts across deeply entrenched ethnocultural divides. At the outset, many of these controversies are seemingly religious or cultural disputes, involving the interpretation of individual rights such as freedom of conscience, freedom of association, and freedom of religion. Yet if we scratch beyond the surface, there is much more at stake in these disputes, or so this paper contends. Broader disagreements that confront majority and minority cultures regarding group rights and the shifting intersections between religion, ethnicity, and gender are played out in these judicial battles. The paper traces the so-called "crisis of multiculturalism" in the European political rhetoric and practice and highlights its impact on the de-juridification of cultural rights and on the tendency to seek accommodation through litigation (typically by minority litigants increasingly frustrated with the political backlash against their rights). It then inquires into the prospects of this strategy, pointing out the limitations courts face when adjudicating identity conflicts pertaining to minority groups traditionally disadvantaged in mainstream political processes. These concerns are illustrated through revisiting a number of controversies over Muslim veils that have been resolved by the European Court of Human Rights. The paper cautiously concludes that a shift toward more participatory political processes is more likely to mitigate the decline of progressive forms of multiculturalism and consolidate minority rights.

Keywords: multiculturalism crisis (or crisis of multiculturalism), minority rights, identity conflict, human rights courts

\section{Introduction}

Identity is at the heart of human life. This is perhaps the ultimate reason for the enduring political and legal battles over cultural recognition and accommodation in contemporary democracies. Over the last few decades, minorities around

*Corresponding author: Neus Torbisco-Casals, Universitat Pompeu Fabra, Barcelona, Spain; International Law Department, Graduate Institute for Internacional and Development Studies, Geneva, E-mail: neus.torbisco@graduateinstitute.ch 
the world have challenged the legitimacy of constitutions, laws, and public policies on the grounds that they marginalize, fail to recognize, or are incompatible with their cultural, linguistic, religious, or other identities. Take, for instance, the debates in Europe and North America about whether the cultures of non-Western immigrant groups, or of native peoples and minority nations, should be explicitly recognised in the public sphere. Admittedly, a significant number of claims are formally raised as exemptions to generally applicable regulations in order to accommodate a particular practice or custom. When granted, such exemptions might be represented as discreet immunities or special arrangements permitted out of pragmatism (as a conflict avoidance strategy, for instance) or as expressions of a weak form of toleration. ${ }^{1}$

But the intensification of these demands as part of the increasing politicisation of identity issues reveals the limitations of this approach. Deep disagreements regarding the status and rights of peoples and of national and ethnic minorities, ${ }^{2}$ the meaning of citizenship, and, indeed, the role of the democratic state in diverse societies are played out in those disputes. This impact has become especially apparent in European cultural wars surrounding the right of Muslim girls and women to wear the headscarf or other religious attire in schools and, more generally, in the public sphere; also, in confrontations over the presence of religious symbols in state buildings, ${ }^{3}$ or the use of religious or customary norms to resolve community or family disputes. ${ }^{4}$

The mobilization of identity groups, particularly of minorities, to advance their claims is not new. It is rather the expansion of identity-driven disputes in constitutional democracies that makes it difficult to deal with these claims on a

1 By "weak toleration" I refer to a non-principled form of toleration, which is more akin to the modus vivendi version that emerged out of the religious wars. See MiCHAEL WALZER, ON TOLERATION 10 (1997), and the discussion infra Section 3.

2 By "ethnic minorities" I refer to groups with a common origin or background that goes beyond strict family genealogies, which can also include immigrants as well as their descendants (whether or not they are full citizens) to the extent that they perceive their identity as closely related to these groups. Following Will Kymlicka, I assume that what can best help distinguish ethnic from national minorities are their different demands. The latter are often territorially concentrated and call for separate institutions in recognition of their aspirations to self-government, whereas ethnic minorities tend to be dispersed and claim a higher role and visibility of difference within the common institutions. See Will KyMLicKA, MULTICUltURAL CitizenSHIP: A Liberal THEORY OF MiNORITY Rights (1995).

3 In Europe, both the famous German (Bavaria) crucifix case, BVerfGE 93, 11 BvR 1087/91 (Ger.) and the Italian Lautsi case, Lautsi and Others v. Italy, App. No. 30814/06, 2011 Eur. Ct. H.R., (2011) (deciding whether religious minorities or secular families are entitled to claim the removal of Christian symbols from public schools).

4 On debates about the status of religious law in the United Kingdom, see MaLEIHA MaLIK, Minority Legal ORders In The UK: MinORities, PluRAlism And The LAW (2012). 
discretionary ad hoc basis, without a conscious principled philosophy that grants legal certainty and enduring solutions. A broader public debate, nonetheless, has been evaded in many countries, particularly in Western Europe, which provides the main focus for the following discussion. To a significant extent, this is due to the enduring authority of an integrationist conception that assumes that, ideally, ethnocultural minorities should assimilate into the dominant culture if they are to become equal members of society. At the legal level, this model stresses generality - that is, the need for common laws and regulations - in order to preserve equality before the law and the unity of the legal order. Regulatory and jurisdictional fragmentations are largely seen as dysfunctions.

But beyond the lasting influence of this monistic, state centred model at the domestic level, ${ }^{5}$ identity claims remain puzzling to legal and political analysts who had assumed that globalization and democratization would significantly weaken identity ties, thus favouring cosmopolitan ideals and reducing the salience of ethnocultural strife. ${ }^{6}$ Instead, just as Western societies have become more homogeneous across states and cultures, and identities are viewed more as chosen than as innate, individuals tend to reclaim their value. Hence, the prevailing narrative of globalisation is also fuelling a parallel process of increasing particularism and legal fragmentation. ${ }^{7}$ This is because minorities of diverse sorts often perceive the expansion of a globalised culture as a veiled hegemonic project, which is not neutral but bears the character of the dominant groups. By seeking a higher degree of political and legal autonomy, these groups try to resist forms of "assimilationism" that rule them.

In short, identity cleavages are more apparent in an age of intense intercultural encounters that have accentuated the relative privileges or

5 On pressures on this model, see Neus Torbisco Casals, Beyond Unity and Coherence: The Challenge of Legal Pluralism in a Post-National World, 77 Revista JuRídica UnIVERSIDAD DE PUERTO RICO 531 (2008).

6 For a critical exploration: MinORity NATIONALISM AND THE CHANGING INTERNATIONAL ORDER (Michael Keating \& John McGarry eds., 2001); WALKER CONNOR, ETHNONATIONALISM: THE Quest For Understanding (1994); Will Kymlicka, Politics In The Vernacular: NATiOnAlism, Multiculturalism AND CiTizenship (2001).

7 James N. Rosenau, Distant Proximities: Dynamics Beyond Globalization (2003); Gunther Teubner, Global Bukowina: Legal Pluralism in the World Society, in GLOBAL LaW Without A State (Gunther Teubner ed., 1997).

8 Eamonn Callan, The Ethics of Assimilation, 115 EтHICs 471 (2005). Callan distinguishes the forms of assimilation that globalisation inevitably brings about from "assimilationism," which expresses an attempt of the dominant group to entrench its power through a selective policy intended to impose their culture. 
vulnerabilities experienced by members of different groups. Democratisation and human rights have certainly provided a more congenial environment for the proliferation of identity demands that are part of what Charles Taylor and Axel Honneth dub "struggles for recognition." As an effect of these developments, features such as ethnicity, gender, nationality, sexuality, or religion have acquired prominence in public debates; they are intentionally vindicated not only to reflect core traits shaping personal identities, but also to express ethical and political commitments (that is, normative views and dispositions towards behaving in certain ways, thus influencing agency).

To be sure, identity traits are social constructs, rather than biological traits. ${ }^{10}$ Yet they retain an ascriptive component that needs to be acknowledged - i.e., people are often identified and treated on this basis, whether they want this or not. Identities and labels thus come to matter for ethical and political life. ${ }^{11}$ Such identity-associated normative commitments shape the type of claims that frame this inquiry, which seeks to revisit a set of crucial concerns about group-differentiated citizenship that retain a central role in mainstream political and legal approaches to identity-driven conflicts. These dominant approaches, I contend, remain largely sceptical about expansive conceptions of human rights encompassing not just individual rights, but also group-differentiated rights aimed at asserting a communal identity or culture beyond the private realm. The roots of this hesitancy can be found in the profound influence that the classical liberal model of engagement with diversity, based on toleration, has been able to maintain, despite the strong objections raised by multicultural critiques. At least in Europe, the alternative difference-based approaches that had started to influence the law and policies of some countries during the late 1980s and 1990s seem to be losing the political battle. ${ }^{12}$ Beyond the obvious impact of the post 9/11 climate, and the unremitting economic crisis, one main challenge to counteract the renewed hostility against minority rights has to do with confronting what David Goodhart dubbed "a dilemma for progressives"13 - namely, the difficulties in

9 Multiculturalism And “The Politics Of Recognition”: An Essay By Charles Taylor (Amy Gutmann ed., 1992); Axel Honneth, The Struggle For ReCognition: The Moral GRAmMar OF Social Conflicts (1995).

10 See Kwame A. Appiah, Stereotypes and the Shaping of Identity, 88 CAL. L. REV. 41, 2000.

11 Id. see also Kwame A. Appiah, The ETHICs of IDENTITy (2005).

12 Should state Infra (370-75) spells out the grounds for this assessment.

13 The expression had originally been used by conservative UK politician David Willets. See David Goodhart, Too Diverse?, Prospect MAGazine, Feb. 20, 2004, available at http://www.prospectmagazine.co.uk/features/too-diverse-david-goodhart-multiculturalismbritain-immigration-globalisation. 
reconciling the ethics of identity with other fundamental values, such as individual human rights and social welfare.

The remaining analysis tries to substantiate this account and identify its more remarkable repercussions in the legal realm. Among them, a central one is the tendency of frustrated minorities to turn to courts and the increasing judicialization of identity and cultural disputes. By exploring the limitations of this strategy, the article seeks to lay the ground for a further reflection on the role of judges in promoting inter-cultural justice and equality. The discussion proceeds as follows. The first section starts with a brief conceptual elucidation aimed at identifying two alternative lines of justification of group-differentiated rights that emerged from the first wave of theoretical scholarship on multiculturalism. I then turn to explore the roots of the prevailing discontent with accommodationist policies and the way in which it is impinging on the rights of ethnocultural minorities. As indicated, the discussion focuses largely on the European context, where the so-called "retreat" from multiculturalism adds to the increasing perception that cultural minorities have lost the political battle. Following I examine the legal impact of this backlash, stressing the de-juridification of minority rights and the ensuing trend to seek accommodation through litigation. The section also reflects on the limitations that courts face in dealing with identity-driven conflicts. While minorities tend to over-estimate what can be achieved by judges, important questions arise as to whether and how public courts can engage the multifaceted dimensions of conflicts of culture and how they can avoid the reproduction of ethnic biases. The on-going dispute over whether Muslim girls and women should have the right to wear traditional headscarves in public spaces is taken as a topical example to illuminate the complexities of minority litigation. The concluding section cautiously reclaims the central role of the political space as a more promising venue for tackling the challenges of identity claims and consolidating the status and rights of minority cultures.

\section{Normative Multiculturalism: Conceptual Foundations}

As explained, the so-called "politicization of identity" brings to the fore political demands that people raise not merely as individuals, but as bearers of a particular group identity. Regardless of how it is formed or changed, identity has a crucial impact on people's life. Acknowledging its social and psychological effects is therefore crucial to comprehend why individuals usually care about 
their attachments and, therefore, why identity becomes morally and politically relevant.

Liberal democratic theories, however, have been criticised for failing to take multiculturalism (and the demands of identity) seriously, seeking to construct a state that ignores the constitutive attachments and identities of citizens and relies, instead, on a homogeneous idea of citizenship that, in actual fact, tends to be biased against non-mainstream groups. However, the term 'multiculturalism' is extremely fluid. Beyond conveying the pervasive fact of diversity (ethnic, cultural, linguistic, religious) in contemporary society, ${ }^{14}$ it has accrued a broad range of theories and policies that confer normative significance to identity and cultural claims raised, most often, by minority groups. Throughout the 1990s, normative multiculturalism emerged as a distinctive stance to confront conflicts of culture and identity against the prevailing liberal model. The ground-breaking work of political theorists such as Will Kymlicka, Charles Taylor, or Iris M. Young emphasised that, while traditional liberal approaches had been productive at promoting democracy and counteracting socio-economic inequalities, they had been less successful at overcoming cultural injustice. ${ }^{15}$ A central contention is that states can harm their citizens not just by denying members of minorities their civil, economic, and political rights, but also by trivialising or ignoring their identities in the public sphere. This is the type of impairment that Nancy Fraser and Charles Taylor identified as a failure of "recognition." According to Fraser, traditional debates on redistributive justice tend to conceal this harm because their main focus is placed on identifying and remedying socio-economic injustice. Instead, cultural injustice is primarily linked to status hierarchies, which are not always reducible to economic ones but rooted in social patterns of interpretation and communication, including cultural domination and stereotypical representations of minority identities. ${ }^{16}$

In the view of critics, the conventional liberal model of citizenship tends to ignore this injustice by recreating a narrative of a single national culture that condemns newcomers to a second-class citizenship and reinforces the disadvan-

14 Race, ethnicity, nationality, religion, and language are the most prominent traits in defining multiculturalism, yet immigrant and sexual minorities raise similar demands of recognition. See Kymlicka, supra note 2; TARIQ Modood, Multi-Culturalism (2013).

15 Kymlicka, supra note 2; Iris Marion Young, Polity and Group Difference: A Critique of the Ideal of Universal Citizenship, 99 Ethics 250 (1989); IRIS MARIOn Young, The Politics OF Difference (1990); Multiculturalism And “The Politics Of ReCognition,” supra note 9. 16 Nancy Fraser, From Redistribution to Recognition? Dilemmas of Justice in A 'Post-Socialist' Age, in Theorising Multiculturalism 70-72 (Cynthia Willet ed., 1998). 
tage of historically marginalised minorities. Granting group rights ${ }^{17}$ to minority cultures, alongside the general rights of citizenship, is seen as key to remedying such failure, thus offering a rationale for legislation and public policies intended to accommodate difference and promote the long-term viability of minority cultures. To be sure, the normative grounds that justify group rights remain contested. ${ }^{18}$ But, for present purposes, it is important to distinguish between two versions of the theory that remain in tension in disputes involving identity or cultural claims.

The more conservative accounts envision the liberal quest for universal human rights and objective principles of justice as misguided and are inclined to prioritise group preservation (or "cultural survival") over individual rights. This justification is typically based on a view of morality as historical and contextual, rather than universal. Ethnocultural groups are depicted in an essentialist fashion, as the primary source of identification for their individual members, and hence in need of protection. As a result, religious and cultural conflicts tend to be portrayed as involving a clash of incommensurable, nonnegotiable values - freedom of choice versus traditionalism and so forth - and cultural rights and accommodations are often defended from a relativist perspective. This picture, as will become apparent, seems to prevail in the usually overstated popular myths about the perils of recognising cultural diversity.

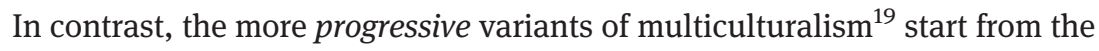
assumption that cultural and identity claims can (and should) be reconciled with the core ethos underlying human rights as inalienable and universal moral rights. While this conception certainly rests upon a more communitarian view of the self as strongly influenced by socialization in a given context, its proponents remain committed to the centrality of individual human agency and the individual's capacity of critical reflection (also about identity) and thus see multiculturalism as compatible with liberal doctrine. On the other hand, cultures, and cultural affiliations and identifications, are conceived as fluid and, in themselves, do not provide justificatory reasons for performing legally prohibited

17 Here I assume that certain group-differentiated rights for minority cultures can qualify as human rights provided that their justification is connected to basic individual interests that members in these groups have in participating and reproducing their own culture (rather than on some irreducible interests attributed to the culture itself). For a detailed elucidation of this view, see Neus Torbisco Casals, Group Rights As Human Rights (2006). See also Peter Jones, Human Rights, Group Rights and People's Rights, 21 HUM. RTS. Q. 80 (1999); David Miller, Group Rights, Human Rights and Citizenship, 10 EUR. J. PHIL. 178 (2002).

18 See TORBISCo CASALS, supra note 17.

19 I borrow this notion from Maleiha Malik, Progressive Multiculturalism: Minority Women and Cultural Diversity, 17 INT’L J. MINORITY \& GROUP RTS. 447 (2010). 
acts, for instance. What matters, then, is not the change, or eventual disappearance, of a culture per se, but the nature of the process that leads to this result. The point is to ensure that members of minority cultures are not coerced to assimilate or to give up their commitments and efforts to preserve their institutions or languages. Finally, progressive defences of multiculturalism typically reject the more radical relativist framework, placing the accent on the need to take cultural pluralism and inter-group equality seriously.

The justification of the rights of minority cultures by Will Kymlicka, probably the leading theorist of multiculturalism, provides a good illustration, ${ }^{20}$ as it recasts the recognition of difference as a necessary implication, rather than as a negation, of the commitment to autonomy. Other influential scholars justify the public accommodation of difference on an equality argument, understood not just as equality of opportunity, but as an equal concern and respect for all groups that compose a society. ${ }^{21}$ Iris Young's defence of a "politics of difference" goes further in characterising the invisibility, misrecognition, or false representation of minority identities as a form of oppression, to the extent that it contributes to establishing the dominant group experience and culture as the norm. $^{22}$

In short, the distinctive feature of this conception has to do with its aspiration to a higher degree of inclusion in shaping the public space. ${ }^{23}$ For instance, the relevance of multiculturalism in an inclusive educational system is justified in order to balance the legitimate claims to diversity (and the significance of identity recognition) with fostering a sense of common belonging. The defence is thus not based upon an essentialist representation of groups, nor on a commitment to their survival as separate entities, but rather on the need of identifying and confronting the relations of domination embedded in social relations and in political structures. Overall, these progressive versions of multiculturalism offer a new grammar to assess the ethics of the broad range of identity demands

20 Participation in a "societal culture," Kymlicka argues, provides the tools for understanding cultural narratives and values, and this, in itself, is a precondition for making meaningful choices about how to lead one's life. Hence cultures (and cultural survival) are instrumentally crucial for individual freedom, and therefore need to be protected, but not intrinsically valued. See Kymlicka, supra note 2. Similarly, Avishai Margalit \& Moshe Halbertal, Liberalism and the Right to Culture, 61 Soc. ReSEARCH 491 (1994); Avishai Margalit \& Joseph Raz, National SelfDetermination, 87 J. PHIL. 446 (1990).

21 Martha Minow, Making All The Difference: Inclusion, Exclusion, And America LaW (1990).

22 Young, supra note 15, at 39.

23 See Modood, supra note 14; BhiKhu PAReKh, Rethinking Multiculturalism: Cultural Diversity AND POLITICAL THEORY (2000). 
earlier described. Its proponents commonly subscribe to a vision of the political community based on a commitment to recognising, rather than transcending, particularity.

\section{Identity Claims, Multiculturalism, and Human Rights: An Incomplete Recognition}

In 2001, Kymlicka identified a growing consensus over what he identified as "liberal culturalism," 24 an expression denoting the progressive forms of multiculturalism described, implying that the case for the rights of minority cultures had been successfully established: "The more cases we study," he wrote, "the stronger is the claim that ethnocultural justice cannot be secured by a regime of common rights." 25 In his view, normative multiculturalism had won the day by successfully challenging the prevailing (individualist and homogeneous) human rights paradigm.

Yet, the implementation of the theoretical consensus perceived by Kymlicka has proved elusive. Thus, the remarkable turn in the political theory of the last two decades has not had the profound institutional impact that proponents of progressive multiculturalism might have expected. Both domestically and internationally, there has been little positive recognition of the rights of minority cultures as collective or group rights (beyond the common human and citizenship rights) capable of producing binding effects. Certainly, constitutional and international human rights norms have played a crucial part in providing a framework for the claims of minority cultures. However, beyond rhetorical allusion to the value of cultural diversity and the general individual right to take part in cultural life, ${ }^{26}$ it is dubious that cultural rights have been fully incorporated in International Human Rights Law as a distinctive legal category involving group differentiated entitlements and tangible state duties. ${ }^{27}$ Even

24 Kymlicka compresses in this term both liberal forms of immigrant multiculturalism and of self-government rights for minority nations and indigenous peoples. See KYMLICKA, supra note 6 , at 9, 42 .

$25 \mathrm{Id}$. at 47.

26 See Committee on Economic and Social Rights, General Comment 21, UN Doc. E/C.12/GC/21 (Dec. 21, 2009).

27 On the limited number of rights attributed directly to groups by international law norms, see Carl Wellman, The Moral Dimensions Of Human Rights (2011). 
though efforts have been made to develop international standards of minority protection and to codify multiculturalism, ${ }^{28}$ most of these standards retain a semi-legal character - they are rather "soft law" regulations or "best practices," which remain largely unenforceable. Besides, the codification of cultural rights retains a strong individualist outlook - rights are formally conferred upon individuals - and many provisions are interpreted merely as negative rights of group members, rather than involving state positive action. As the group dimension of these claims tends to be neglected, ${ }^{29}$ in practice, claims of culture are frequently reduced to individual civil and political rights, such as freedom of association or religion, as these rights offer a safer site to claimants. Only the increasing recognition of the rights of indigenous peoples constitutes a significant exception to this pattern, due, perhaps, to the recognition of the need to confront historical injustices. ${ }^{30}$ On the other hand, a very small number of states have incorporated explicit references to multiculturalism or to minority rights in their constitutions. ${ }^{31}$

However, the partial juridification (and, in particular, the limited entrenchment of the rights of ethnocultural minorities in instruments such as constitutions or human rights regulations) is perhaps not yet indicative of the lack of impact of normative multiculturalism. As Kymlicka himself acknowledges, ${ }^{32}$

28 For analyses, see Philip Alston, Peoples' Rights (2001); PAtrick Thornberry, INTERNATIONAL LAW AND THE RightS OF MinoRities (1991); MinORITY RightS IN EuROPE: A REVIEW OF THE WoRK AND STANDARDS OF THE COUNCIL OF EUROPE (Patrick Thornberry \& Maria Estebenez eds., 2004); Minorities, Peoples AND SELF-Determination: EsSAys IN Honour of PATRICK THORNBERRY (2005).

29 Cultural rights have recently attracted greater interest, but most studies use the notion largely as an umbrella for different individual rights related to culture. See CULTURAL HuMAN RightS (Francesco Francioni \& Martin Scheinin eds., 2008); CORE OBLigations: BuILDing A FRAMEWORK FOR ECONOMIC, SOCIAL AND Cultural Rights (Audrey Chapman \& Sage Russell eds., 2002); Laura Reidel, What are Cultural Rights? Protecting Groups with Individual Rights, 9 J. HuM. RTS. 65 (2010).

30 The adoption of the UN Declaration on the Rights of Indigenous Peoples (G.A. Res. A/RES/ 61/295 (Oct. 2, 2007)) represented a great achievement, as several provisions explicitly recognise collective rights. The constitutional recognition of indigenous tribes is also a growing trend. See Kirsty Gover, Tribal Constitutionalism. States, Tribes and the Governance of MEMBERSHIP (2010).

31 The Canadian Charter of Rights and Freedoms of 1982 (Part I of the Constitution Act, 1982, being Schedule B to the Canada Act, 1982) offers a remarkable exception, as it explicitly refers to the preservation and enhancement of the multicultural heritage of Canadians; likewise, the South African Constitution (S. Afr. Const., 1996.) recognizes the right to participate in one's own cultural life.

32 Will Kymlicka, Multicultural Odysseys. Navigating the NeW International Politics OF DIVERSITY (2007). 
there are limits as to how much those general legal instruments can capture the relevant specificities of the claims made by minority cultures in different contexts. Instead, the increasing global commitment to multiculturalism and minority rights can be perceived through the expansion of policies intended to accommodate multiple identities in the public realm. And, indeed, those policies had gained considerable ground throughout the late 1980s and 1990s in multiethnic and multi-national democracies such as Canada, Britain, or the Netherlands. Initially, this development came about to face up to the need of integrating new waves of postcolonial migration without drawing on purely assimilationist strategies; on the other hand, a number of countries have adopted asymmetrical forms of federalism (or models of shared sovereignty) in order to accommodate their linguistic and national minorities. ${ }^{33}$

\section{The Backlash against Multiculturalism: Dissecting the Roots of Discontent}

Nevertheless, as a number of sociologists and political analysts have increasingly noticed, ${ }^{34}$ the last decade has witnessed a retreat in this accommodationist trend, affecting a variety of programmes and regulations aimed at institutionalising diversity and promoting a difference-based model of integration. As a political trend, the backlash against multiculturalism is especially noticeable in Europe, ${ }^{35}$ where the model has come under intense pressure in countries that had (officially or semi-officially) recognized and granted specific entitlements to minority cultures. The case of the Netherlands, where publicly supported multiculturalist programmes had been central since the 1980s, has come to epitomize the main patterns of a broader shift. The model started to be under pressure in the late 1990s, when the growing presence of non-Western immigrant communities, especially Muslim minorities, came to be represented as a threat. Initially, the critique of both immigration and multiculturalism by a number of influential public intellectuals helped to validate the growing popular dissatisfaction,

33 For a comparative assessment of this trend, see Michel Seymour \& Alain G. Gagnon, Multinational Federalism: Problems and Prospects (2012).

34 See, e.g., Christian Joppke, The Retreat of Multiculturalism in the Liberal State: Theory and Policy, 55 Brit. J. Sociology 237 (2004); Derek McGheE, The End of Multiculturalism? TERRORISM, INTEGRATION AND HUMAN RIGHTS (2008).

35 The Multiculturalism Backlash: European Discourses, Policies and Practices (Steven Vertovec \& Susanne Wessendorf eds., 2009); Magdalena Lesinska, The European Backlash against Immigration and Multiculturalism, 50 J. SocIOLOGY 37 (2014). 
ultimately paving the road for the institutional setback. ${ }^{36}$ At the outset, discontent focused on multiculturalism as a model characterized by an excess of toleration that runs the risk of producing an ethnically segregated society. Then, in an increasingly (post 9/11) hostile political environment, two dreadful domestic events triggered the official endorsement of this narrative. First, the murder of Pim Fortuyn - an independent candidate who came close to become Prime Minister with a strong anti-immigration and anti-Muslim discourse during the 2002 national election campaign prompted the announcement of a substantial reform of the immigration policy with the purpose of introducing tighter restrictions to immigration and cancelling programmes designed to accommodate ethnic minorities. The reform was seen as an essential step to counteract what Fortuyn and his followers saw as an increasing Islamisation and ghettoization of society. Two years later, the assassination of filmmaker Theo Van Gogh $^{37}$ by a Dutch-Moroccan Muslim contributed to the legitimisation of a broader shift of policy, even among those who had previously criticised the need for reforms. ${ }^{38}$

The shift of discourse in the Netherlands is not unique. Across the continent, political leaders of all signs have vociferously announced the "failure" and the "death" of multiculturalism. ${ }^{39}$ There has been much political talk about the perils of multiculturalism turning into a dangerous form of exclusion, as it supposedly allows the proliferation of racial and religious ghettos depicted as a danger for social cohesion and human rights. This is essentially what Trevor Phillips, then Chair of the UK Commission for Racial Equality, claimed in his controversial "Sleepwalking to Segregation" speech, ${ }^{40}$ delivered in the wake of the 2005 London bombings. Since then, Phillips' main claims about the real impact of migration in Britain, and the supposed "unwillingness" of migrants to integrate, have been seriously challenged. ${ }^{41}$ Still, by 2011, the newly elected Prime Minister, David Cameron, openly defied what he called "state

36 See, e.g., Paul Cliteur, De Filosofie Van Mensenrechten (1999).

37 Van Gogh was murdered shortly after the release of his film Submission I, a publicly broadcasted movie, which made controversial statements about Islam.

38 Ellie Vasta, From Ethnic Minorities to Ethnic Majority Policy: Multiculturalism and the Shift to Assimilationism in the Netherlands, 30 ETHNIC \& RACIAL STUD. 713 (2007).

39 See John Bowen, Europeans against Multiculturalism, Bost. REv. (2011), available at http://www.bostonreview.net/john-r-bowen-european-multiculturalism-islam; THE MulTicultuRALISM BACKLASH: EUROPEAN DisCOURSES, POLICIES AND PRACTICES, supra note 35.

40 See Audrey Gillan, Ghettoes in English Cities 'Almost Equal to Chicago', ThE GuARdian, Sept. 23, 2005, available at http://www.theguardian.com/uk/2005/sep/23/race.world.

41 Nissa Finney \& Ludi Simpson, Sleepwalking To Segregation? Challenging Myths About RaCE AND Migration (2009). 
multiculturalism" (meaning Britain's long-standing state-sponsored policy) as an "abysmal failure," linking it to separatism and to the failure of providing a common vision of society. Cameron claimed that a more active form of "muscular liberalism" based on shared values was needed to counteract the rise of Islamic extremism and so-called "home grown" terrorism. ${ }^{42}$

As it is apparent, a common concern unifying the growing anti-multiculturalism stance is that public policies designed to encourage positive respect for the languages, symbols, and religious traditions of minorities have failed to integrate their members in the mainstream society, creating "parallel societies." To be sure, the aftermath of 9/11 - especially the threats associated to global terrorism that proponents of multiculturalism could not anticipate in the 1990s - and the global economic crisis are central factors impelling the picture of multiculturalism as "balkanising" the liberal state. In Europe, the London and Madrid bombings have strengthened conservative agendas that support the hardening of immigration policies and the securitisation of the relations between the state and minorities (especially ethnic minorities) deflecting attention away from questions of intercultural justice and equality. ${ }^{43}$ For this reason, critics tend to see this rhetoric as the result of neo-nationalist and irresponsible xenophobic discourses that exploit popular fears and economic insecurities for electoral purposes.

In short, the backlash against multiculturalism is typically depicted as the preserve of neo-conservative movements at a time where politicians need to react to pathological social fears provoked by the escalation of terrorist acts in the name of Islam. The anti-multiculturalist talk also serves as a pretext for right wing governments to evade their responsibility for the rising inequalities fuelling the discontent of the middle classes, diverting the blame to immigrants (portrayed as flooding an overstretched job marked and abusing the welfare benefits system ${ }^{44}$ ). The nationalist imaginary of social unity and common values

42 A full transcript of the 2011 speech of David Cameron, UK Prime Minister, at a Security Conference in Munich, available at http://www.newstatesman.com/blogs/the-staggers/2011/02/ terrorism-islam-ideology.

43 Beyond Europe, similar shifts in discourse can be observed. Even Canada, once the paradigmatic example of the success of multiculturalism, is immersed in heated discussions about its relative merits and failures. See Keith Banting \& Will Kymlicka, Canadian Multiculturalism: Global Anxieties and Local Debates, 23 BRIT. J. CAN. STUD. 43 (2010); the 2008 report by Gerard Bouchard and Charles Taylor (Co-Chairs of the Consultation Commission on Accommodation Practices Related to Cultural Differences, set up by the Quebec government) summarizes the reasons underlying the discontent. See CHARLES TAYLOR \& GÉRARD BOUCHARD, BUILDING THE FUtURE: A TIME FOR RECONCILIATION (2008).

44 See, e.g., http://www.sueddeutsche.de/politik/armutseinwanderung-cdu-streitet-ueber-fin gerabdruecke-fuer-bulgaren-und-rumaenen-1.1855119; http://www.telegraph.co.uk/news/ 
has thus become a key discursive device to demand sacrifices from citizens, such as shouldering the burden of the economic crisis.

Yet, a crucial feature of the growing anti-multicultural stance, at least in the European context, is that it also seems to be winning the minds of progressives. In the case of Britain, it was a Labour government (that of Gordon Brown) that in fact introduced significant policy adjustments (such as a citizenship ceremony for new nationals, involving an oath of allegiance to the Queen along with a pledge to respect the rights, freedoms, and common values ${ }^{45}$ ). These adjustments have been interpreted as a significant change of strategy, which adopts a "securitisation" approach to ethnic relations and involves rebalancing human rights with duties in order to protect society - hence, the insistence on the notion of shared values and on the discourse on preserving Britishness. ${ }^{46}$ The increasing introduction of citizenship tests is similarly perceived as an illustration of a major change. ${ }^{47}$

Surely, the shift could be interpreted as a mere rhetorical attempt by anxious political leaders that need to counteract the rise of extreme-right and populist parties. ${ }^{48}$ But this understanding cannot fully account for the reluctant attitude towards minority rights displayed by many social liberals, radical democrats, and feminists alike, who have not voiced a strong disagreement with the official rejection of multiculturalism.

Multiculturalism, indeed, raises weighty challenges beyond the conservative realm. One crucial issue points to the potential trade-off between supporting cultural and identity claims and preserving social rights. As pointed out in the introduction, this is well captured by what a decade ago David Goodhart polemically identified as a "dilemma for progressives."49 As the argument goes, it is dubious that a very diverse country (as Britain, in his view, had become) can be able to sustain the type of mutual obligations and the high degree of cooperation necessary to preserve a strong redistributive system. ${ }^{50}$

uknews/immigration/10996721/David-Cameron-announces-immigration-benefits-crackdown. html.

45 See also Ministry of Justice (UK), THE GovernAnCE of BritAin (2007), available at https://www.gov.uk/government/publications/the-governance-of-britain.

46 See MCGHEE, supra note 34.

47 For a comparative study of citizenship tests, see Ines Michalowski, Required to Assimilate? The Content of Citizenship Tests in Five Countries, 1 Citizenship STUd. 749 (2011).

48 See Mabel Berezin, The Normalization of the Right in Post-Security Europe, in PoLITICS IN THE AGE OF AuSTERITY (Armin Schaefer \& Wolfgang Streeck eds., 2010).

49 Goodhart, supra note 13.

50 See also DAvid Goodhart, The British DreAm: Successes AND FAILURES OF POST-WAR IMMIGRATION (2013). Theorists of liberal nationalism have stressed that the sense of common 
On the other hand, multiculturalism has been pitted against feminism, and against liberal secularism, too. Feminist commentators often regard identity claims and cultural accommodations as suspicious because of its potential for women's oppression. Susan Okin originally raised this central objection in a famous essay entitled "Is Multiculturalism Bad for Women?" (1997). ${ }^{51}$ The argument, which can be extended to other vulnerable groups within minorities, runs roughly as follows: insofar as group rights strengthen the boundaries between communities (by demarcating spaces of collective self-government relatively free from external interference), they could worsen the situation of their most vulnerable members, namely, of the minorities within minorities. ${ }^{52}$ In particular, to the extent that group rights are attributed to patriarchal groups that neglect women's rights, oppressive practices and collective self-understandings of the community that reinforce female subjugation could be implicitly legitimised. ${ }^{53}$ There is a conundrum here, which Ayelet Shachar defines as a "paradox of multicultural vulnerability," 54 whereby well-intentioned efforts aimed at enhancing group autonomy and mitigating inter-group power inequalities can easily lead to reinforcing intra-group hierarchies and aggravating the subordination of vulnerable groups. From a human rights perspective, the anxiety is especially focused on the risk of overlooking human rights violations (such as sexual violence or discriminatory rules of membership) within minority groups.

A last facet of the dilemma for progressives concerns the potential of accommodationist practices, and differentiated forms of citizenship, to jeopardise state neutrality and the separation between church and state. ${ }^{55}$ Liberal theorists of multiculturalism have paid insufficient attention to the status and rights of religious minorities, as they usually start from a presumption in favour of secularism that entails a form of state neutrality based on a strict separation

belonging fostered by nationality has been central in expanding solidarity beyond primordial attachments. See DAVID Miller, ON NATIONALITY (1995).

51 Susan Moller Okin, Is Multiculturalism Bad for Women?, 22 Bost. REv. 2 (1997).

52 For a discussion, see Minorities Within MinoRities. Equality, Rights AND Diversity (Avigail Eisenberg \& Jeff Spinner-Halev eds., 2005).

53 On the risk of ignoring internal contestation, see AnNe Phillips, Multiculturalism Without Culture (2007); Madhavi Sunder, Cultural Dissent, 54 Stanford L. Rev. 495 (2001). 54 Ayelet Shachar, The Paradox of Multicultural Vulnerability: Individual Rights, Identity Groups and the State, in Multicultural QueSTIONS ch. 5 (Christian Joppke \& Steven Lukes eds., 1999). 55 While maintaining diametrically opposed understandings of liberalism, Brian Barry and Chandran Kukathas coincide in this conclusion. See CHANDRAn KuKATHAS, THE Liberal ARChipelago: A THEORY OF Diversity AND FreEdom 12-15, 75-77 (2003); see also Brian Barry, Culture And Equality: An Egalitarian Critique of Multiculturalism (2001). 
between the public and the private realms. ${ }^{56}$ The objection, as stressed by Tariq Modood, is particularly compelling in Europe, where most countries contain sizeable Muslim minorities whose demands often bear a religious component. ${ }^{57}$

\section{Questioning the Retreat: Real or Just Discursive?}

As it is apparent, the anti-multiculturalism stance is not homogeneous and has been used in a multiplicity of critical discourses. As Alana Lentin and Gavan Titley put it:

[T] he range of processes of social dissolution and varieties of anomie that multiculturalism is held responsible for is scarcely credible (...). As a loose assemblage of culturally pluralist sentiments, aspirations and platitudes, or more darkly as an euphemism for lived multiculture, it provides a mobilising metaphor for a spectrum of political aversion and racism that has become pronounced in Western Europe. ${ }^{58}$

On closer inspection, most of the statements quoted above are based on a caricatured version of multiculturalism that hardly captures the progressive variants supported by its most serious advocates. The predominant political narrative associates it to the conservative model as described in the previous section, which seems to involve the full abdication of the state's duty to promote social integration. Kymlicka himself has criticised the idea of multiculturalism "as a feel-good celebration of ethnocultural diversity." 59 Such a misguided picture ignores, he says, the normative dimension of a doctrine that emerges as part of the human rights movement ${ }^{60}$ and proposes a more inclusive model of democratic citizenship in order to confront group-based injustices.

Furthermore, the dilemmas identified have been seriously contested in the scholarly literature. First, the suggestion that, as a normative policy, multiculturalism leads to segregation has been authoritatively challenged as a myth

56 KyMLICKA (supra note 2, at 111) offers a good example, as he highlights the inconsistencies of the classical model of liberal toleration as implying that, in principle, the state should adopt a "hands-off" approach to culture. Yet his argument still assumes that the state can indeed remain neutral regarding religion.

57 Tariq Modood, Anti-Essentialism, Multiculturalism, and the 'Recognition' of Religious Groups, 6 J. POL. PHIL. 378 (1998).

58 alana Lentin \& Gavan Titley, The Crises of Multiculturalism. Racism in a NeOliberal Age (2011); for a similar critique: Bowen, supra note 39.

59 Will Kymlicka, Multiculturalism: Success, Failure AND the Future (2012), available at file://C:/Users/home/Downloads/TCM-Multiculturalism-Web.pdf.

60 Id. at 4-8. See also KyMLICKA supra note 32, at 88-96. 
reflecting a misrepresentation of knowledge. According to Nissa Finney and Ludi Simpson, this idea, as well as the notion that there are "too many migrants" and that minorities are "unwilling" or "difficult" to integrate reflects an unfounded perception that these authors try to uncover using statistical data extracted from the same sources on which such misperceptions seem to be based. ${ }^{61}$ Likewise, there are grounds to think that multiculturalism policies are neither detrimental to redistribution (and thus cultural recognition is compatible with preserving social rights) nor to democracy. ${ }^{62}$ In response to feminist concerns, a rich body of literature has emerged that tries to move beyond the "multiculturalism versus feminism" debate and identify specific problems and strategies to address Okin's challenge in a way that reduces potential tensions and conciliates cultural and identity claims with women's rights. ${ }^{63}$ Finally, the force of the mainstream secularist critique is limited, as it tends to overlook the hegemonic or privileged status that the dominant religion has retained in the mainstream cultural values and practices and its enduring influence in law and society. ${ }^{64}$

However, debunking the empirical and normative underpinnings upon which this set of negative ideas about multiculturalism is generally based might be insufficient to changing a discourse that is gaining popular and political currency. The context in which myths about ethnic relations and community cohesion emerge is crucial, and the objections outlined have a strong influence in the widespread rejection of normative multiculturalism. As the previous analysis reveals, those myths are often wilfully reproduced to validate a shift of discourse in the face of growing discontent and rising populist parties. The impact of such strategically oriented political rhetoric might explain why, somehow paradoxically, the hostility against multiculturalism has even been proclaimed by heads of state in Germany and France, two countries where, in actuality, the multiculturalist model has never been adopted. Yet German Chancellor Angela Merkel and former French President Nicholas Sarkozy went

61 Finney \& Simpson, supra note 41. For a defence of the model, see Banting \& Kymlicka, supra note 43.

62 See Cultural Diversity Versus ECONOmic Solidarity (Philippe Van Parijs ed., 2004); on the challenges that diversity poses to trust as a basis for democracy and possible avenues to overcome them, see Patti Lenard, Trust, Democracy And Multicultural Challenges (2012).

63 See PHILLIPS, supra note 53; Ayelet Shachar, Group Identity and Women's Rights in Family Law: The Perils of Multicultural Accommodation, 6 J. Pol. Phil. 285 (1998); and Ayelet Shachar, Multicultural Jurisdictions. Cultural Differences And Women's Rights (2001); Sarah Song, Justice, Gender And The Politics Of Multiculturalism (2007).

64 See Harry Judge, The Muslim Headscarf and French Schools, 111 AM. J. ED. 1 (2004). For a general critique on the separation between politics, culture, and religion: Modood, supra note 57. 
on to proclaim the death of multiculturalism, ${ }^{65}$ in an attempt to please the rising number of conservatives within their own parties and to counteract, especially in the French case, the growing popular support of extreme right anti-immigration parties. ${ }^{66}$

Still, against what the wholesale political discredit of multiculturalism might suggest, the retreat has been questioned by several academics, Will Kymlicka among them. The main contention is that the backlash described is mostly rhetorical and limited in scope. Whatever the discourse might suggest, empirical research shows that, at the local level, the diversity rationale continues to inform policy and accommodations, even if out of necessity or mere pragmatism. Drawing on these accounts, the highly publicised retreat would be more a matter of politicians avoiding the use of the word "multiculturalism" in response to the shift in public attitudes towards immigration and religious or national minorities - and favouring other terms, such as "pluralism" - than a real change of policy. ${ }^{67}$

But commentators are divided over this optimistic interpretation. In Europe, sociologists such as Christian Joppke have argued that the political retreat has indeed resulted in a shift of policy, as it permeates the policy agenda in a wide range of areas, such as anti-terrorism law, race relations, education, and access to citizenship and welfare. ${ }^{68}$ For example, the trend towards adopting more compulsory forms of integration into common national values or identity is hardly refutable. And while citizenship tests might be interpreted as a symbolic reaction, they do impose an extra burden to members of minority groups and thus signify a step back into assimilationism. Other regressive measures have been adopted that considerably limit cultural rights and policies, as in the case

65 In a controversial statement made in October 2010, Merkel misleadingly characterized multiculturalism as an attempt to build a "multi-kulti" society consisting in living "happily side by side," which, in her view, had failed in making immigrants integrate. Sarkozy made similar remarks in a discourse aimed at justifying bans on Islamic veils as necessary to preserve secularism and French identity.

66 For an interpretation of French developments that stresses the crucial role of the popularity of the National Front Party, see Joan Wallach Scott, The Politics of the VeIL (2007). On the relation between the anti-multiculturalist discourses and emerging forms of racism, See LENTIN \& TITLEY, supra note 58. On the emergence of right-wing populism in Europe, see MABEL Berezin, Illiberal Politics in Neoliberal Times. Culture, Security and Populism in the NEW EUROPE (2009).

67 KYMLICKA, supra note 59; TAYLOR \& BOUCHARD, supra note 43.

68 Joppke, supra note 34; and The Retreat is Real - But What Is the Alternative? Multiculturalism, Muscular Liberalism, and Islam, 21 Constellations 286 (2014). See also Lesinska, supra note 35. 
of national and linguistic minorities in Spain $^{69}$ or of religious groups in France. ${ }^{70}$ The goal is, to a significant extent, to dismantle special legal regimes and return to a model of "one society, one citizenship, and one law for all," often grounded on an unapologetic attempt at excluding certain identities from the public sphere.

In short, there are reasons to remain cautious about claims that deny the real impact of the retreat. Although disputing the empirical grounds for this assessment would require a separate empirical inquiry, two observations are relevant from the normative perspective that concerns us here.

On the one hand, speech is politics, too. Whatever their deeper motivations, political discourses do have a practical impact, as they provide the grounds for legitimising institutional and legal changes. Thus, the transformational potential of what some scholars interpret as a mere rhetorical move should not be neglected. However, unsound the empirical and normative grounds that justify the anti-multiculturalism stance might be, the expanding public concern has significantly weakened the consolidation of group-differentiated rights.

On the other hand, even if the rhetorical shift had not (yet) affected policy substantially, there are limits to the more pragmatist version of multiculturalism tacitly supported by those who question the impact of the retreat. ${ }^{71}$ Most significantly, this is a version that falls short of the progressive account of multiculturalism, as outlined herein, which is principle-based and focused on justice for minorities. Both the recognition of rights and the transformation of the political and legal order to make it more sensitive to difference are central in this paradigm. If, instead, group-differentiated accommodations are adopted ad hoc, out of prudential or pragmatic reasons, then the politics of difference is essentially tied to the fate of political action. Under this conception, minority accommodations might be best conceived as "permissions" (discretionarily granted and thus revocable) rather than as genuine rights (which would confer "immunities" to minorities against the state).

Against this objection, it could be argued that local accommodations and exemptions might still be based on a more principled account of toleration. ${ }^{72}$ But the toleration model usually falls short of a politics of recognition and equal respect for minority cultures. It requires the self-restraint of the majority, which

69 On the instructive case of Catalonia, see infra note 79.

70 President François Hollande has hardened the anti-multiculturalist discourse of his predecessor, and has supported a law that completely bans the wearing of burqas in the public space. 71 For an extended discussion, see Joppke, supra note 68.

72 See, e.g., WALZER, supra note 1, at 14-19; Samuel Scheffler, Immigration and the Significance of Culture, 35 PHIL. \& PuB. AFF. 93, 111-16 (2007). 
can be fulfilled simply by enforcing negative duties - such as the duty to not harm minority groups, or to avoid policies of forceful assimilation. But it is one thing, say, to avoid forcing non-Christian religious groups, or linguistic minorities, to give up their beliefs and languages, and quite another one to grant them, as a group, equal status and recognition in the public sphere. ${ }^{73}$ Toleration, moreover, presumes a hierarchical relation of subjection based on asymmetrical power. Minorities are perceived as subjected to the state authority, an object of regulation, which determines the terms of accommodation. That is why being tolerated feels "uncomfortable," as Leslie Green puts it. ${ }^{74}$ It often presupposes an adverse judgment on a given practice or tradition that is accompanied by an effort to authorise it that is neither grounded on moral acceptance or recognition. A toleration approach thus simply assumes the unequal standing of cultural minorities in the mainstream political culture. ${ }^{75}$

Interpreted in this light, the legal adjustments that some countries made in response to identity claims might have been part of a politics of toleration, more inspired on what Jacob Levy dubs a "multiculturalism of fear""76 than on a "multiculturalism of rights." If this is so, then it hardly makes sense to talk about the multicultural retreat, as it would be more accurate to acknowledge that the model has hardly been applied. In fact, the sort of unabridged rejection of normative multiculturalism would be almost unthinkable if progressive defences of multiculturalism had really transformed the predominant legal orthodoxies. This is so because demands put forward in the language of rights often act as strong normative reasons that enjoy priority, ${ }^{77}$ thus generating "waves of duties" should be institutionally fulfilled in order to protect them.

\section{A Limited Scope?}

For the reasons discussed so far, the impact of the retreat from multiculturalism should not be underestimated. Yet it could still be argued that the scope of the

73 For a rich discussion on the normative limitations of this conception, see RAINER FORST, TOLERATION In CONFLict: PAST AND PRESENT (2013).

74 Leslie Green, On Being Tolerated, in The Legacy Of H.L.A Hart: Legal, Political, And Moral Philosophy (Mathew Kramer et al. eds., 2008).

75 See also Forst, supra note 73, at 29-30 (discussing an alternative conception based on equal respect).

76 See Jacob Levy, The Multiculturalism of Fear (2000).

77 See Ronald Dworkin, Taking Rights Seriously (1997); and Ronald Dworkin, Rights as Trumps, in THEORIES OF RIGHTS (Jeremy Waldron ed., 1984).

78 Jeremy Waldron, Rights in Conflict, 3 ETHICs 503 (1989). 
retreat is limited, taking into account what progressive models of multiculturalism actually prescribe. In Europe, at least, the backlash against cultural accommodations seems to be affecting mostly immigrants and ethnic minorities, largely of Muslim origin. And the trend towards political devolution appears globally stable, which might call into question the gloomier assessments about the retreat.

There is a kernel of truth in these observations. Still, conflicts such as the one between Spain and Catalonia offer an example of how the refusal to understand cultural and self-government claims as human rights can leave minority groups defenceless against the encroachment of their rights and political status. To a significant extent, the current dispute has originated in a re-centralisation move justified through assimilationist discourses that deny the relevance of difference and the need of accommodating Catalan demands for broader autonomy. This shift is largely based on the belief that the decentralisation model adopted in the 1978 Spanish Constitution to accommodate national and linguistic minorities has proved divisive, leading to an incremental dynamic of demands. However, the setback on minority rights has triggered massive protests, as it is not merely symbolic but affects broad policy areas such as education and linguistic policy. The growing perception that the central state's laws and financial regulations are being systematically used to encroach on the powers devolved to the Catalan self-government institutions is, stirring secessionist demands. ${ }^{79}$

On the other hand, even acknowledging the undeniable link between the pressure on multiculturalism and the social perception of Islam and of Muslim minorities as a threat, it is crucial to recognise that these are the most prominent (and politically salient) minority groups in Europe. Hence, the backlash against accommodations cannot be dismissed as limited simply because it mainly targets Muslims. $^{80}$

79 For a brief recount of these events, see Xavier Vilà Carrera, The Domain of Spain: How Likely is Catalan Independence?, WORLD AFF. (2014), available at http://www.worldaffairsjournal.org/ article/domain-spain-how-likely-catalan-independence. See also, Xavier Cuadras-Morató (ed.): Catalonia: A New Independent State in Europe? A Debate over Secession within the EUROPEAN UNION (2016).

80 The anti-multiculturalist talk in other countries has also focused on prominent groups, such as Hispanics in the United States and Asians in Australia. See Christian Joppke, Through the European Looking Glass: Citizenship Tests in the USA, Australia and Canada, 17 CITIZENSHIP STUD. 1 (2013). 


\section{Rights, Identity, and Courts}

\section{De-juridification as an Effect of the Retreat from Multiculturalism: Bans on Veils as an Illustration}

The priority so far has been to trace the grounds for the current fragility of progressive variants of multiculturalism. The persistent lack of consensus on the morality of minority (group-differentiated) rights as human rights is surely influenced by the elusiveness of the dilemmas sketched, which also explains the relatively weak opposition to the backlash. In the legal realm, a notable implication of the fall of multiculturalism is the significant weakening of the process of juridification of identity (group-based) claims that had started to shape human rights law in the 1990s. The normative aspirations of proponents of multiculturalism have thus been deflated, giving way to much more local and fragmented group rights regimes. This de-juridification trend displaces questions of human rights and legitimacy, which had been key to the embryonic development of an international legal framework for minority protection. As a result, the more powerful groups in each state have the ultimate say on recognition and accommodation.

While de-juridification significantly increases the discretionary powers of the dominant majorities, it does not necessarily entail de-regulation. On the contrary, there is a growing tendency to regulate the boundaries of the settlement between society, religion, and culture, which, as McCrea notes, "have to date been a matter of socio-cultural convention rather than legal rule." ${ }^{81}$ Far from subsiding, state law moves in once social consensus dissolves and inter-group conflict is perceived as intractable. In Europe, the proliferation of legal norms that attempt to re-define those boundaries takes place against the background of hostility towards minorities described earlier. The reversal of accommodationist policies tends to be justified as necessary to preserve individual rights, social cohesion, and the "public order". This reinforces the oversimplified conception of group rights and individual rights as mutually excluding categories; as it is often put: "it is either your culture or your rights." 82

In the face of this dilemmatic depiction, the adoption of prohibitionist strategies in order to target potentially threatening practices or customs has

81 Ronan McCrea, The Ban on the Veil and European Law, 13 HUM. RTS. L. REV. 58 (2013).

82 For a general critique of rights-based approaches to conflicts of identity that stresses the shortcomings of this framing, see Avigail EISENBERG, REASONS OF IDENTITY: A NORMATIVE Guide to the Political and Legal Assessment of Identity Claims (2009). 
become more common. The polemic expansion of the so-called "veil bans" across Western Europe over the last decade is particularly revealing of this attempt at regulating contested identities and restricting their public expression in the name of preserving individual rights but also the identity of the polity. As is well known, a significant number of states (most notably France, but also Belgium, Denmark, and Switzerland) have adopted a varied range of legal restrictions on the wearing of Muslim veils in various forms - from the hijab or headscarf to the body-covering Arabic burqa and the more Afghan-style niqab. ${ }^{83}$ To be sure, not every country has legislated at the national level; but several regional or local governments have banned (or announced their intention to ban) full Islamic face-veils from certain public spaces. ${ }^{84}$ So far, such constraints remain mostly circumscribed to specific areas, including state schools, courts, public libraries, or government facilities. But calls to broaden these restrictions are persistent, as polls show that the majority of citizens support them. Most notably, in the case of the controversial Belgium and French full-face veils (known as burqa bans) the prohibition has been extended to all public spaces. ${ }^{85}$

To be sure, none of these bans are formally targeting Muslims as a group, nor do they refer specifically to women or to the Islamic veils directly. For instance, a French statute of 2004 prohibits all students in public elementary schools and high schools from wearing symbols or clothes through which their religious affiliation is conspicuously (ostensiblement, in the French formulation)

83 The word "hijab" comes from the Arabic for veil. Islamic normative sources prescribe that women ought to dress modestly, but the female modest dress code is interpreted in a great variety of ways. In Western Europe, a relatively small number of Muslim women understand it as requiring a full covering of the body, with the exception of the face and hands; but what most of them wear is not a gown but a square-shaped headscarf, which comes in myriad styles and covers the head and neck but leaves the face clear.

84 Local and regional authorities in Italy, Germany, Spain, or Switzerland have approved restrictions. In Northern Italy, several municipal bans have been adopted. In Germany, the Federal Constitutional Court ruled in 2003 in favor of a teacher who wanted to wear an Islamic scarf to school, but some Länder have banned school teachers from wearing it. Similarly, although there is no national law restricting the wearing of veils in Switzerland or Spain, in 2013, the Italian-speaking Swiss region of Ticino voted in favour of a ban on face veils in public areas, and the Catalan city of Lleida had adopted restrictions on full Islamic face-veils in some public spaces, too - however, Spain's Supreme Court overturned the ban in February 2013, ruling that it was outside the municipality competence.

85 On the problems of such bans, see also the Resolution 1743 (2010) of the Parliamentary Assembly of the Council of Europe on Islam, Islamism and Islamophobia in Europe, para. 17; and Recommendation 1927, 2010, para. 3. 13. 
displayed. ${ }^{86}$ Accordingly, the ban also applies to the Jewish skullcap (or kippa), the Sikh turban, and to any Christian cross that is too visible (as opposed to discreet). The same observation is true for most restrictions, including the more recent full-face veil ban in France. Its first section reads: "No one may, in public places, wear clothing that is designed to conceal the face." ${ }^{87}$ Hence, they usually apply to "any group" and can potentially affect a variety of head garments or religious dress. ${ }^{88}$

Nevertheless, the fact that the adoption of these legislative measures had been preceded by a nearly obsessive political fixation with Islamic veils mimicked, too, in the media - makes it hard to see this prohibitionist trend in a neutral vein. Even if the prohibitions are not openly targeting Muslim women, they do have a particular impact in undermining their opportunities and ways of life, thus putting them at a disadvantage in relation to the dominant social and religious group. As noted by Muslim scholars, the headscarf is not just a religious symbol, but also a genuine duty that Islamic Law prescribes for the public social space. ${ }^{89}$ So, forcing women to remove the headscarf represents a serious restriction of their freedom of religion and conscience, and also affects their equality of opportunity in the access to public jobs or to pursue education.

If we look at this issue merely through an individual rights prism, the very fact that the regulation of Muslim attire has deserved such an intense public and legislative attention seems disproportionate. Actually, there are very few Muslim women wearing full-face covering body gowns, such as niqabs and burqas, and most of them interpret Islamic normative precepts as simply requiring them to cover the hair with a headscarf. ${ }^{90}$ As some analysts observed with respect to the first ban on veils adopted in France, wearing a headscarf in class was seen as militantly anti-French. ${ }^{91}$ What the law incorporated, then, was not just a state-

86 Code DE L'ÉDUCATION [National Code of Education] (Fr.), art. 141-5-1 No 2004-228.

87 Law no. 2010-1192, Oct. 11, 2010 (Fr.).

88 For a comparative analysis, see Dominic MCGoldRick, Human Rights AND RELiGion: The IsLAMiC HEADSCARF DEBATE IN EUROPE (2006).

89 Shadid Wasif \& Pieter Van Koningsveld, Muslim Dress in Europe: Debates on the Headscarf, 16 J. IsLAmic Stud. 36 (2005).

90 See France's Ban on the Burqa: The War of French Dressing, THE ECONOMIST, Jan. 16, 2010, at 49, available at http://www.economist.com/node/15270861; Maurits S. Berger, The Netherlands, in THE OXFORD HANDBOOK OF EUROPEAN ISLAM 158 (Jocelyn Cesary ed., 2014).

91 Norma Claire Moruzzi, A Problem with Head Scarves: Contemporary Complexities of Political and Social Identity, 22 Pol. THEORY 656 (1994); Jane Kramer, Taking the Veil. How French Public Schools became the Battleground in a Culture War, 22 NEW YORKER 58 (2004). 
ment on secularism or equality, but also the reaffirmation of French national identity. ${ }^{92}$ The whole turn to regulating minority symbols and behaviour is, therefore, part of the growing social anxiety about ethnocultural diversity.

As suggested earlier, from a jurisprudential perspective, it is one thing to grant an exemption to a given group and another, very different question, is how to face to the demands for differentiated legal arrangements that are based on a broader discourse of recognition. As Modood states, Muslim's demands are both religious and political. ${ }^{93}$ This is because their identities cannot remain just private, as their faith includes prescriptions that encompass a broad range of rules concerning interpersonal interaction beyond the family and their religious community. ${ }^{94}$

In sum, with its characteristic obsession to regulate the public manifestation of religion, the spread of bans on veils illustrates the decline of a multicultural model of integration. The complexity of the veil symbol highlights the intersecting issues of ethnicity, religion, secularism, gender equality, and also fears of terrorism, which cut across the traditional right and left divides. From this perspective we can make sense of the fact that, for many young female Muslims, wearing the headscarf has become a reactive form of asserting their identities (rather than just their faith) in the face of increasing intolerance. ${ }^{95}$

\section{Courts and Culture: Limits of Litigating Identity Conflicts}

A second critical effect of the retreat of multiculturalism in the legal realm is the trend to seek recognition and accommodation through litigation. As ethnocultural minorities see their status and rights increasingly threatened by an adverse political climate, which they have little hope to influence given their structural marginalization in the mainstream institutions, they turn to courts for protection. Through this strategy, they seek an affirmation of what they see as entitlements, and not merely as concessions granted out of toleration. As a result, judges, rather than legislators, are playing a central role in dealing with cultural clashes and identity claims that confront majority and minority cultures. This raises questions as to whether the judicial sphere provides the best

92 On the negative association of "multiculturalism" with "exceptionalism," see Kramer, supra note 91 .

93 Modood, supra note 57, at 385-87.

94 Id. at 387.

95 Marnia lazreg, Questioning The Veil. Open letters To Muslim Women 55 (2009); Jennifer A. Selby, France, in The Oxford HANDBook OF European Islam 30-34 (Jocelyn Cesary ed., 2014). 
context in which to settle these disputes or, on the contrary, it might exacerbate them yet further.

At the outset, there are reasons to think that the essential role of the judiciary in protecting vulnerable minorities, which is usually invoked in objections to the counter-majoritarian critique of judicial review, ${ }^{96}$ places public courts in a good position to assess the demands of identity. The judiciary, as Hamilton famously claimed, might indeed be the "least dangerous" branch "to the political rights of the Constitution," as it has "no influence over either the sword or the purse; no direction either of the strength or of the wealth of the society." 97 In the context of the political backlash described, the judicial setting can provide a forum for public deliberation and visibility of minorities whose interests and views are typically underrepresented or simply excluded from the mainstream political sphere. Hence, the judicial mobilisation of minorities could increase the opportunities for inter-cultural interaction and give courts the chance to unsettle unfair systems, help inform public understandings, and subvert the position of privilege of dominant identity groups. When rulings (especially those that come from particularly prestigious courts, either domestic or international) reflect an effort to hear the voices of women, or of racial, ethnic, gay, and religious minorities, and to treat their reasons fairly, they have a potential for helping to overcome dominant prejudices against these groups as well as stereotypes of their members. Eventually, this might help to generate a virtuous circle of inter-cultural understanding and higher social empathy towards minorities.

But even acknowledging the transformational potential of public adjudication, there are a number of considerations that should moderate this optimistic account. The idealised view of judges as impartial and almost infallible authorities, who can act as a safe haven from majoritarian prejudice, underestimates the concerns about institutional constraints and biases that might not just impinge on the courts' ability to protect vulnerable groups, but also undermine significantly the required impartiality of adjudicators. Here, it is important to recall that the composition of courts (both domestic and international) is made up of middle and upper class professional elites (mostly male) that, in most cases, are also members of the majority culture.

Surely, it could be objected that cultural belonging and political ideology do not need to determine, and that they should ideally not even influence, the task of adjudication. But there are solid critiques that challenge this idealised view.

96 See Alexander Bickel, The Least Dangerous Branch (1962).

97 Alexander Hamilton, The Judiciary Department, in THE FEDERALIST PAPERS 78, 590 (Alexander Hamilton, James Madison, \& John Jay, eds., 2007) [1788]. 
The more radically sceptical stance is associated with American realist theorists who crucially pointed out that judges are ordinary persons, too, with a personal background and an identity, and that factors such as their education, religion, political views, and cultural belonging can influence their reasoning. ${ }^{98}$ Even those who reject the most critical realist accounts against judicial impartiality should acknowledge that the contrary ideal - a Dworkinian depiction of Hercules (the immensely wise judge with full knowledge and unlimited time to decide $^{99}$ ) - remains a metaphor. There is a risk that the cultural, ethnic, and gender imbalances that are typical of the judicial bench across Western democracies affect impartiality, and that judicial decision-making ends up reproducing dominant prejudices and biases. Although it is not possible to engage in depth with the substantial questions that the lack of internal diversity in the composition of the courts raises, ${ }^{100}$ let me briefly elaborate on the relevant issues that might affect the adjudication of identity and cultural conflicts.

The principle nemo iudex in causa sua - that is, no judge should preside over a matter in which she has a personal interest - is regarded as fundamental in democratic legal systems. Yet in cases concerning the assessment of minority practices or symbols, it is not a direct or even conscious personal interest that can be potentially threatening, but rather a more unconscious prejudice. This can be manifested more subtly in processes of adjudication led by judges who are typically male and belong to the dominant ethnocultural group. For instance, such judges might simply attend less carefully to the facts of the case, or display a lower level of "perceptual sensitivity"101 towards the reasoning or arguments invoked by minority claimants. Although giving a proper normative account of this dimension of judging is a task that cannot be undertaken here, the idea is well captured by Amalia Amaya's argument that the practical reasoning of a virtuous (decision-making) agent is not merely dependent on applying a set of general principles or rules, but on showing the capacity to

98 For an illuminating reconstruction of this doctrine, see BRIAN LEITER, NATURALIZING JURISPRUDENCE: ESSAYS ON AMERICAN LEgAL REALISM AND NATURALISM IN LEgaL PHILOSOPHY (2007).

99 RONALD DWORKIN, LAW'S EMPIRE (1988).

100 There is an increasing interest in exploring the impact of the lack of diversity in the composition of courts (both domestic and international). See, e.g., Nienke Grossman, Sex on the Bench: Do Women Judges Matter to the Legitimacy of International Courts? 12 CHICAGo J. InT'L L. 647 (2012). See also UK LABOUR PARTY REPORT, JUdiCIAL DivERSITY: ACCELERATING CHANGE, available at http://ukscblog.com/judicial-diversity-accelerating-change-reportpublished.

101 See Maksymilian Del Mar, Judging Virtuously: Developing an Emphatic Capacity for Perceptual Sensitivity, 5 JURISPRUDENCE 177 (2014). 
recognise the salient features of a given situation ${ }^{102}$ - and, I would add, of attributing legal salience to certain social facts and symbols.

Empathy might play a crucial role in conflicts involving cultural minorities, especially when it comes to judging unfamiliar behaviour or practises that are typically attributed to "other" cultures. Yet, the capacity to show empathy might not come as an effortless skill. Unlike what the term might suggest at first sight, the point is not primarily one of developing an emotional identification leading to sympathizing with the feelings of minority litigants, as this might damage impartiality, too. Rather, as Maks Del Mar stresses, empathy is not just an affective state, but has an important cognitive dimension as well. ${ }^{103}$ This dimension can be significantly abridged if the adjudicator is not critically aware of the likely presence of biases or prejudices, or if she is insufficiently attentive or alert to the social contempt against certain identities.

The problem, in brief, is one of adjudicators being less mindful, and hence less objective and impartial, in assessing the claims of minority litigants, as their capacity to be responsive to their "otherness," and to assess their reasons fairly, might simply be impaired by their position as members of the dominant culture. As a result, judgments might replicate, and contribute to solidifying, existing social prejudices. Moreover, to the extent that minorities perceive the judicial processes (or the outcomes) as biased against their identities, this will have negative impact on the perception of the legitimacy and the authority of public courts.

In addition to these general concerns about impartiality, two other potential limitations to the litigation strategy are relevant:

First, in light of existing institutional constraints - both procedural and substantive - minorities should not overestimate what courts can achieve. Judges are not legislators, and are required to act as legal rather than as moral agents. In order to preserve democracy and the rule of law, their institutional function is circumscribed to interpreting and applying legally binding norms. ${ }^{104}$ Hence, in adjudicating a given dispute, they are simply not allowed to ground their decisions on their own ideas about what is fair or just, but on arguments that constitute a valid legal justification.

Certainly, human rights norms and fundamental rights are typically expressed through abstract and vague clauses that incorporate contested

102 Amalia Amaya, The Role of Virtue in Legal Justification, in LAW, VIRTUE \& JUSTICE 51 (Amalia Amaya \& Ho Hock Lai eds., 2013).

103 See Del Mar, supra note 101.

104 A map of the relations between democracy and courts and the ways in which democracy shapes adjudication, see JUdiTH RESNiCK \& DENNIS CURTIS, REPRESENTING JustiCE (2011). 
concepts. In this context of judicial discretion, adjudicators could certainly adopt a more activist position, based on the development of an emphatic concern for the particular experience of the minority claimant, with the aim of upholding minority rights. But judges cannot create new legal rights, and leave legal rules out altogether, as their job consists in interpreting and applying existing law (domestic or international), which, as noted before, has, for the most part, not yet incorporated the multiculturalism paradigm.

Second, the idea that public adjudication can further the democratic inclusion of marginalised groups tends to ignore the fact that judicial disputes take the form of contradictory processes. When demands of identity that transcend the individual case are at stake, these processes can magnify cultural divides and exacerbate the sense of mutual distrust and disaffection. Moreover, as noted above, if the reasoning of judges, or the outcomes of adjudication, are perceived by minority litigants as biased or prejudiced against their identities, this perception can be detrimental to the very authority of the courts. Minorities might then seek to withdraw from mainstream institutions, including public adjudicatory processes, and create their own systems of regulation and adjudication.

\section{An Illustration: Jurisprudence of the European Court of Human Rights in Cases concerning Bans on Veils}

A brief review of the European Court of Human Rights jurisprudence (hereinafter, ECtHR or "the Court") in cases involving state laws banning Islamic headscarves might be useful to illuminate the limitations of minority litigation just outlined. Offering a comprehensive account of the jurisprudential development on freedom of religion in Europe would require an extensive investigation that is not possible here. ${ }^{105}$ The restricted focus on a few ECtHR cases is thus merely aimed at illustrating those constraints. Certainly, as an international body, the Strasbourg court faces specific institutional limitations that have to be acknowledged. ${ }^{106}$ Nevertheless, unlike other international tribunals, the Court has come to acquire a privileged and influential position in Europe, more similar to that of a supra-national constitutional court. This means that the judgments it produces are crucially relevant for the interpretation of domes-

105 See norman Doe, LAW ANd Religion In Europe: A Comparative Introduction (2011); Ronan McCrea, Religion ANd the Public Order of the European Union (2010).

106 See The European Court of Human Rights Between LaW and Politics (J. Christoffersen \& M. Rask Madsen eds., 2011). 
tic and international human rights law. ${ }^{107}$ In addition, the internal composition of the Court reflects the lack of ethnocultural diversity, which, as noted, is common among high level domestic courts and international tribunals. ${ }^{108}$

Going back to the judicial conflicts emerging from state-imposed restrictions to the wearing of Muslim headscarves, in a line of well documented cases, the Court has taken a decisive stance in favour of the state interest to ban certain religious symbols or attire in the public sphere. ${ }^{109}$ As a result, the Contracting States enjoy a broad discretion to interfere legitimately in the public expression of religious beliefs, through the adoption of specific prohibitions and sanctions. The acceptance of restrictions on the individual right to manifest religion recognised in the European Convention of Human Rights ${ }^{10}$ (hereinafter ECHR) has been justified on different grounds, including the preservation of the "public order," "public safety," and "the rights and freedoms of others." Under such generic restrictions, the Court has referred to the overriding right of the state to shape public education and the public sphere; also, to the need of guaranteeing gender equality and preserving secularism.

From the perspective of the limits of minority litigation, we should first note that the predominant judicial framing in terms of individual rights in conflict already obscures the broader ethnocultural dimension of disputes on headscarves, including its historical and socio-political roots. At the outset, the Court is presented with what they see as a familiar legal challenge of demarcating the legitimate exercise of the individual right to freedom of religion in the face of competing claims - equality and non-discrimination, health and security,

107 I focus here on the ECtHR as the court of final appeal on rights-related issues, and I leave aside the institutional complexities stemming from its character as an international court insofar as they are not central to understanding its substantive reasoning. For reasons of space, I do not discuss the treatment of the issue by domestic courts, in which the European cases originated.

108 On the procedure of appointment, still largely centred on nominations by national governments, see Council of Europe Parliamentary Assembly, Election of Judges, available at http://website-pace.net/en_GB/web/as-jur/echr-judges-election. Critical accounts can be found in SELECTING EuROPE'S Judges (M. Bobek ed., 2015).

109 I focus here on decisions in which the Court has considered the compatibility of headscarf bans with the right to freedom of religion and other rights recognised in the ECHR: Dahlab v. Switzerland, Application no. 42393/98, 2001 Eur. Ct. H.R. 447 (2001); Leyla Şahin v. Turkey, App. No. 44774/98, Eur. Ct. H.R. (2004) (G.C.); Dogru v. France, Application no. 27058/05, Eur. Ct. H.R. (2008) and Kervanci v. France, Application no. 31645/04, Eur. Ct. H.R. 1579 (2008); S.A.S v. France, Application no. 43835/11, July 1, 2014.

110 European Convention for the Protection of Human Rights and Fundamental Freedoms, art. 9, Nov. 4, 1950, 213 U.N.T.S. 222, amended by Protocol 3, Sept. 21, 1970, Eur. T.S No. 45, Protocol 5, Dec. 20, 1971, Eur. T.S. No. 55 and Protocol 8, Jan. 1, 1990, Eur. T.S No 118 [hereinafter ECHR]. 
public order and so forth. However, this legal framework obscures considerations about group inequalities, domination, and structural discrimination, which transcend the discreet individual case at hand. Thus, not much consideration is given to the minority group's perception or likely reaction to the process and judgment. Moreover, contestation (inter and intra-cultural) about the meaning of the symbol or practice often remains blurred in the judicial context. This increases the risk of gender and ethnic bias, especially when courts fail to explore the symbols or practices at stake in all their complexity and simply endorse the predominant interpretation as authoritative.

Take, for instance, the most recent case of S.A.S. v. France, which challenged the French "burqa ban" on wearing face coverings in public spaces. The Grand Chamber of the ECtHR. held that the absolute prohibition of the concealment of a person's face in public did not violate the ECHR. The applicant was a practicing Muslim living in France who declared her occasional choice to wear religious clothing that conceals her face, such as a burqa or a niqab. She claimed that the 2011 law prohibiting the concealment of a person's face prohibited her from wearing religious clothing of her choosing and violated her rights under Articles 3 (cruel and degrading treatment), 8 (private life), 9 (freedom of religion), 10 (freedom of expression), and 11 (freedom of assembly and association) of the ECHR separately and in conjunction with Article 14 (freedom from discrimination). ${ }^{111}$ After declaring inadmissible the applicant's claims under articles 3 and 11, the Court focused principally on the compatibility of the French law with Articles 8 and Article 9 of the Convention. The ban, it found, interferes with, and limits, the exercise of these rights. Yet the State asserted, and the Court accepted, that such interference was justified as it pursued two "legitimate aims" that were "necessary in a democratic society": "public safety," and "respect for the minimum set of values of an open and democratic society."

With regard to the first justification, the Court found that a blanket ban on full face covering would only be proportionate in the case of a general threat, which the French government did not demonstrate. ${ }^{113}$ Still, the Court acknowledged that the French legislature intended to address issues of public safety that may arise from the concealment of faces in public. To this extent, the judgment contributes to legitimizing, de facto, the feelings of "lack of safety" or "uneasiness" associated with the veils, and the general suspicion of headscarves and other minority symbols. As the explanatory memorandum to the French Law explicitly states: "the wearing of the full veil is the sectarian manifestation of a

111 S.A.S v. France, supra note 109, paras. 3, 10-14.

112 Id. paras. 110-22.

113 Id. para. 139. 
rejection of the values of the Republic" and "brings with it a symbolic and dehumanizing violence." ${ }^{114}$ Yet, as noted in the joint partly dissenting opinion of Judges Nussberger and Jäderblom, those feelings and fears are not directly linked to the veil itself, which can hardly be perceived as aggressive, but to the "interpretations of its symbolic meaning." "The ruling, however, fails to critically assess this widespread interpretation, and thus automatically privileges the radical significance that the state attributes to the full veil symbol (as potentially threatening public safety) in detriment to the alternative meaning endorsed by the claimant (who claims that her choice to wear the full-face veil is neither aimed at offending or threatening others, but "to feel at inner peace with herself""116).

This point becomes even more crucial when it comes to the analysis of the State's second justification, which is not explicitly listed in the Convention as an acceptable reason for restricting individual rights. Nevertheless, the Court draws a connection between the notions of "living together" and "respect for the minimum requirements of life in society" with the legitimate aim of the "protection of the rights and freedoms of others."117 The majority thought that the impugned ban could be regarded as justified, as it seeks to guarantee the preconditions of "living together"; and "a State may find it essential to give particular weight in this connection to the interaction between individuals and may consider this to be adversely affected by the fact that some conceal their faces in public places."

But once again, in deciding that wearing clothing that conceals the face in public is incompatible with "the ground rules of social communication,"119 the Court seems to be automatically privileging the conception and forms of interpersonal exchange that are accepted as "normal" and as an expression of "tolerance and broadmindedness" by the dominant culture to which the judges themselves belong. ${ }^{120}$

Certainly, as in other controversial cases, the Court practices a largely unconstrained deference to the state assessment, framed in terms of its well-

114 Id. para. 25.

115 Id. para. 8 (Judges Nussberger and Jäderblom jointly partly dissenting).

116 Id. para. 12.

117 Id. para. 121. This is explicitly listed in ECHR, supra note 110, arts. 8 \& 9 (para. 2 of each).

118 Id. para. 141.

119 Id. paras. 153-54.

120 The separate opinion by Judges Nussberger and Jäderblom regards public communication as a right, not a duty; the interference, they think, is disproportionate because it affects intimate rights related to identity and personality. See S.A.S v. France, supra note 109, para. 9 (Judges Nussberger and Jäderblom partially dissenting). 
known "margin of appreciation" doctrine. ${ }^{121}$ This doctrine is based on the idea that the State is "in principle better placed than an international court to evaluate local needs and conditions," "122 especially in cases where the Council of Europe Members States display a lack of consensus. Yet, in judicial cases that critically confront majority and minority cultures, unless a stricter test of proportionality is undertaken, ${ }^{123}$ the prudential subsidiary role asserted by the Court might have the effect of reinforcing domestic majoritarianism, instead of pluralism, thus privileging collective goals over the rights of members of minority cultures.

In a nutshell, judicial decision-making in cases involving minority litigants runs the risk of ignoring the complex and multifaceted dimensions of a given practice or symbol - a risk that might be even accentuated when conflicts are decided in the context of international human rights courts facing additional institutional constraints. On the one hand, the judges' own ethnic or cultural biases (consciously or unconsciously) can led them to overlook the contestation surrounding a particular cultural or religious symbol or practice, and instead accept the most radical or extreme meanings that the majority culture attaches to them (such as the veil's intrinsic offensiveness); on the other hand, the inherent institutional constraints of judicial controversies (such as the typical "rights in conflict" framing) usually obscures the collective and multifaceted dimensions of conflicts involving minority cultures, as well as the impact of a given ruling in reinforcing the domination of one cultural group over the other.

As the account in the previous section shows, there is much more than veils involved in the public debate that has led to these judicial battles. Minority litigants are not merely claiming their right to manifest their religious belief; they are also making a statement about identity and non-discrimination. By overlooking the particular collective impact of bans such as the one described on the position of a given group in society (for instance, accentuating their marginalisation), public adjudication systems can actually foster the hardening of the conflict as well as the sense of distrust and vulnerability felt by members in minority groups.

121 See, George Letsas, Two Concepts of the Margin of Appreciation, 26 Ox. J. LEGAL STUD. 705 (2006). 122 S.A.S v. France, supra note 109, para. 129. This jurisprudential doctrine originates in Handyside v. United Kingdom, App. 5493/72, 24 Eur. Ct. H.R. (ser. A) (1976).

123 The dissenting judges in the S.A.S case not only challenge the proportionality of the ban, but they also argue that the State should not have been granted such a broad margin of appreciation. S.A.S v. France, supra note 109, paras. 13-24 (Judges Nussberger and Jäderblom partially dissenting). 
In truth, the ECtHR has started to display certain awareness of these problems. Hence, in the S.A.S case, it acknowledges that the blanket ban might be too broad and, despite its formal neutrality, primarily affects Muslim women and is regarded as disproportionate by a large number of international and domestic actors. $^{124}$ But the judgment ultimately diminishes the significance of these factors by asserting that the ban was not intended to target Muslim women (a dubious contention, taking into account certain Islamophobic remarks that preceded its adoption), that the penalty for a violation is relatively minor, and that it ultimately corresponds to the state, portrayed as a "neutral and impartial organiser of the exercise of various religions,"125 to strike a balance between the potential rights at stake in its society. ${ }^{126}$

Beyond the case just explored, the ECtHR jurisprudence on veils also brings to light the risk of reinforcing prejudices against unpopular minorities. Thus, in the judgments of Dogru and Kervanci (both applications against France for banning the headscarf in physical education and sports classes) the ECtHR. avoids scrutinising whether the restrictions were necessary to protect health (hygiene) and safety and uncritically accepts that it is "reasonable" to think so, without further factual investigation. It also stresses that the local dispute over headscarves had created a "general atmosphere of tension," implying that minorities were somehow responsible for this anxiety, instead of considering that they might be in fact victims of discriminatory stereotypes. ${ }^{127}$

As regards gender biases, the S.A.S decision crucially appears to reject the previous jurisprudence in the cases of Dahlab and Sahin, where the Court seems to endorse the representation of headscarves as symbols of female subordination, and therefore portrays the wearing of this garment by two adult women as an implicit acceptance of gender inequality. ${ }^{128}$ These contested associations were a crucial part of the reasoning that led the Court to uphold the measures adopted by the Swiss and Turkish governments, respectively. ${ }^{129}$ In the Dahlab case, the applicant was a Swiss primary school teacher who was requested to take off her headscarf while performing her teaching duties. The headscarf was deemed incompatible with the Canton of Geneva Public Education Act, which

124 S.A.S v. France, supra note 109, paras. 145-46.

125 Id. para. 127.

126 Id. paras. 151-52, 154.

127 See Dogru v. France, supra note 109 and Kervanci v. France, supra note 109, paras. 13, 74. 128 Instead, in S.A.S, the Court rejects as erroneous the suggestion that the ban is primarily concerned with protecting gender equality and remains unconvinced that women who wear the full-face veil do so under coercion or duress. See S.A.S v. France, supra note 109, paras. 118-19, 137. 129 For a critical stance, see Jill Marshall, Conditions for Freedom? European Human Rights Law and the Islamic Headscarf Debate, 30 HuM. RTs. Q. 631 (2008). 
requires the public education system to respect pupils' and parents' political and religious beliefs. The ECtHR framed the issue as one of weighing the teacher's right to manifest her religion against the need to protect pupils "by preserving religious harmony" (despite neither pupils, nor their parents, having complained) and the judges agreed with the Swiss government that "it therefore appears difficult to reconcile the wearing of an Islamic headscarf with the message of tolerance, respect for others, and, above all, equality and nondiscrimination that all teachers in a democratic society must convey to their pupils."130

In the case of Şahin, the applicant was a Turkish medical student at Istambul University who, after having left to Vienna to continue her studies, challenged the Turkish law banning the Islamic headscarf at universities and other educational and state institutions under the European Convention, arguing that her exclusion from university due to her insistence on wearing the headscarf violated her freedom of religion. The ECtHR also upheld the Turkish law: All but one judge of the Grand Chamber accepted that, while the applicant's exclusion from university interfered with her freedom of religion, the interference was justified, among other aims, to promote women's equality.

Leaving aside the problem of neutrality, in both cases the Court accepts that the headscarf stands for women's inequality and portrays the choice of the applicants as not fully autonomous, even though both are adult women who declare that they freely decided to wear it. As a result, the state interference is interpreted as discouraging a harmful choice, rather than as a disproportionate restriction of a right. Yet this paternalistic impulse is based upon a mere suspicion or abstract risk, which is not seriously substantiated throughout the judgment. In Dahlab, the Court itself recognises that it is very difficult to determine the impact of the headscarf on the freedom of religion or conscience of primary school children, as it was uncontested that Ms. Dahlab had avoided engaging in any action suspicious of proselytism. ${ }^{131}$ Still, the Court found that the veil results from a prescription "difficult to reconcile with the principle of equality of the sexes" and "with the message of tolerance, of respect for others and above all of equality and non-discrimination that, in a democratic society, every teacher must transmit to his or her pupils."132

So, the headscarf is inscribed with a single symbolic meaning that excludes alternative narratives, which entails taking at face value the abstract risk of influencing or offending others invoked by the State, as well as the perils of

130 Dahlab v. Switzerland, supra note 109, at 13, sect.1.

131 Id. para. 13.

132 Id. 
radicalisation of beliefs (in Şahin ${ }^{133}$ ) and even of proselytism (a mere fear, yet unsubstantiated, reproduced in both judgments ${ }^{134}$ ). Yet as John Stuart Mill famously argued, a mere potential offence or harm to "society" cannot justify the state interference in the freedom of individuals. The argument was prominently used by H.L. Hart against Lord Devlin in their famous dispute on the prohibition of homosexuality, ${ }^{135}$ and was rehearsed by Judge Tulkens in her solo dissenting opinion in Şahin - where she argued that only irrefutable facts, "and not mere worries or fears," could justify the interference with a right guaranteed by the ECHR. ${ }^{136}$

Finally, the arguments used by the Eur.Ct.H.R. are suspected of applying a higher standard of scrutiny to practices typical of minority cultures, overlooking the fact that many practices and customs of women in the dominant (self-styled as liberal) society have also been informed by the internalisation of patriarchal and discriminatory norms, which in turn keep supporting gender hierarchies within the mainstream culture, too. ${ }^{137}$ So, even if Muslim women did wear the headscarf out of a process of indoctrination, the Court's reasoning would remain problematic to the extent that the level of inspection of majority practices seems less strict - and such double-standards clearly compromise fairness. ${ }^{138}$

\section{Conclusion: Reclaiming the Political?}

The first part of this article contends that the retreat of multiculturalism is quite real, at least in Europe, and takes this fact as evidence that minority rights are far from consolidated as genuine human rights. Although turning to courts is an obvious move for minorities to reclaim what they took as morally justified entitlements - rather than as mere legal exemptions granted out of toleration - I have tried to show that there are obvious limitations in this strategy and, as a consequence, the results might be rather disappointing for minority litigants.

133 Şahin, supra note 109, para. 109.

134 Dahlab, supra note 109, para. 13; Şahin, supra note 109, para. 108.

135 See H.L.A. Hart, LAW, LiBERTY AND MORALITY (1963), which was in part directed against the argument at the basis of Lord Devlin's THE ENFORCEMENT OF MORALS (1965).

136 See Şahin (Judge Tulkens dissenting, para. 5); S.A.S v. France, supra note 109, para. 7 (Judges Nussberger and Jäderblom jointly partly dissenting).

137 Sarah Song, Majority Norms, Multiculturalism, and Gender Equality, 99 AM. PoL. SCI. REV. 473 (2005).

138 See EISENBERG, supra note 82 (arguing when confronting conflicts of identity, judges should be guided by a duty of "institutional humility" in order to avoid imposing more stringent restrictions on members in minority group). 
The legal and political dispute over whether Muslim girls and women should have the right to wear traditional headscarves in public spaces illuminates the pitfalls of the predominant frameworks, centred as they are on individual rights. As shown in the preceding section, there are serious concerns as to the fairness of public adjudicatory processes and the ability of judges to engage the multifaceted dimensions of identity conflicts. The Eur.Ct.H.R.'s jurisprudence, for instance, tends to ascribe Muslims values that contradict human rights and liberal values, such as attributing a lesser role to women, and pursuing practices that are regarded as segregationist or suspicious. It thus reinforces a static view of the headscarf and of the Muslim identity that has been rejected by members of this group, including women, but serves its purpose as an object of criticism and to justify the prohibitionist approach; yet, by ignoring these different interpretive levels, judges engage in a dogmatic application of biased particularistic values in the name of defending human rights.

The courtroom, therefore, might prove an even less egalitarian framework for contestation and protection of group related identity claims than the political realm, as judicial procedures do not usually offer an adequate space for internal contestation and inter-cultural dialogue. For these reasons, I agree with Vernon Bogdanor in that "it is a mistake to overburden the judiciary by giving judges the duty to resolve complex social problems, problems that they are ill-trained to resolve."139 Courts, as Bogdanor rightly contends, cannot be expected to deal with the wider problems facing a multicultural society. There is the danger, as this article has tried to show, that judicial disputes on sensitive cultural issues end up having counterproductive effects, such as to solidify prevalent prejudices against unpopular minorities, and to reaffirm hostility and resentment in divided societies. Progressive multiculturalism should be preferably enhanced through democratic political processes focused on the direct participation of minorities and designed to meet the demands of inter-group justice in diverse democracies. ${ }^{140}$ Such processes, however, should assume the equal moral standing of minority cultures, which is essential to empowering these groups as valid interlocutors with genuine rights and the ability to shape the public space, rather than just merely protecting or tolerating them. Eventually, such procedures might help to overcome the oversimplified views and stereotypes about minorities that dominate judicial (rights-based) approaches, and can produce

139 Vernon Bogdanor, Overcoming the Legacy of the 20th Century: Protecting Minorities in Modern Democracies, available at http://www.scribd.com/doc/120310546/Overcoming-theLegacy-of-the-20th-Century-Protecting-Minorities-in-Modern-Democracies.

140 See Monique Deveaux, Gender and Justice in Multicultural Liberal States (2007). 
enduring settlements out of mutual recognition rather than just provisional judicial victories.

Acknowledgment: This article was written and accepted for publication in 2014; hence the analysis of some of the specific issues discussed (in particular, the European debates about Muslim headscarves) do not take into account more recent legal and political developments. I am very grateful to Nico Krisch for his valuable comments and to Patti Lenard for her support and helpful criticism. I also wish to thank participants in workshops at Universitat Pompeu Fabra, the 2014 Inaugural Conference of the International Society of Public Law in Florence, and the 2014 UK IVR Conference in London for comments and discussions. 